Original Research Paper

\title{
Determining Causes of Gully Erosion and Associated Rates of Change in South-East Nigeria, using a Remote Sensing and GIS Methodology
}

\author{
Sylvanus Iro \\ Department of Geography and Environmental Management, Imo State University, Owerri Nigeria, Nigeria
}

\author{
Article history \\ Received: 02-07-2020 \\ Revised: $19-10-2020$ \\ Accepted: 21-10-2020 \\ Email: arbihuq@gmail.com
}

\begin{abstract}
The study of gully development on a regional scale is currently threatened by the intrinsic costs associated with steady field tracking and monitoring and the lack of historic measurements to perform time series analysis. The research objective is to develop a low-cost GIS and Remote Sensing methodology for monitoring and quantifying gully erosion and development over time, identifying the impact and incorporating analysis of environmental factors and land use change. The analysis of study area topography at $30 \mathrm{~m}$ resolution reveals $85 \%$ of the surveyed gullies develop on concave slopes with high values of 6 plan curvatures and $>50$ inclines. Results also reveal high association with ferralsols soils. Statistical analysis to determine significance of variables on the proportional yearly gully change in metre squared per square metre were conducted via principle component analysis. The analysis of this work was restricted to the time periods 2006/7, 2009/10 and 2014/15. The approach did not report any existence of one singular driver of erosion across the studied years and multiple sites confirming the complexity of gullies. The PCA showed that the level of variance explained in the yearly gully change variable was most similar in PC1 (representing the component with the highest eigenvalue) to Vegetation loss, Vegetation loss and slope in the respective years. The study offers a method of monitoring gully development from early stage to maturity and exemplifies the complexity and variability of erosion drivers in the SE Nigeria region. It presents a verified approach to local and regional monitoring of gullies, enacted through use of low budget/computing cost remote sensing and classification technologies and serves to embolden civilian and governmental efforts to manage the societal and environmental menace of gully erosion.
\end{abstract}

Keywords: Gully Erosion, Rates of Change, Remote Sensing and GIS

\section{Introduction}

The formation of gully erosion and sediments are a function of rainfall, soil properties and topography and can be induced by human interference including land management practices. The rainfall intensity is high in this area of Nigeria and often persists for long durations. Storms with over $25 \mathrm{~mm} / \mathrm{h}$ intensity have been reported by (Hudson, 1981) to be particularly erosive. Igwe (2004) observed in the region that most gullies develop at slopes, cuestas, fractures and joints which are common features in the gully-erosion-prone areas of Southeast Nigeria and have been identified as significant factors in the formation of gullies and subsequent erosion. The study area has also seen increased erosion rates through the exacerbating effect of mineral extraction sites (Gobin et al., 1999; Okagbue and Uma, 1987). The loss of soil degrades arable land and eventually renders it unproductive. As a result, there are significant per capita shortages of arable land. The effects of this erosive 
action are made more severe by recent and rapid population growth in the Southeast region of Nigeria. Loss of agricultural output is one of the greatest economic costs of gully erosion (Pimentel, 2004). Unquantified large portions of land have been degraded in recent years in towns such as Ekwulobia, AguluNanka, Orlu, Iyioku, Njaba, Igboukwu, Okigwe, Abiriba, Mbaise, Uturu, Ideato, Amucha. In addition, infrastructure and in particular roads, have been damaged, leading to numerous vehicle accidents and displacement of residential houses. Several studies have been conducted on the causes of gully erosion in Southeast Nigeria and ways to control them. Most of the studies primarily revolve around causes based on the immediate scenario rather than the long term causes as can be found in (Igbokwe et al., 2008; Ezezika and Adetona, 2011). They also deal more with combating gully erosion rather than its prevention and pay little attention to methods of managing this natural hazard.

\section{Study Area}

Gully Erosion occurs in numerous areas within the South-East states of Nigeria. Erosion problems arise mainly from natural causes, but their extent and severity are increasingly attributed to anthropogenic ignorance and unintentional action (Enabor and Sagua, 1988). In spite of technological advancement including land-use planning (UNDP, 2015), run-off catch pits (Igbozuruike, 1989) and drainage channels (Nekatet, 2006), gully erosion still remains a major problem in the region. The academic community has observed that gully erosion, is largely a result of natural factors including rainfall run-off (Njoku et al., 2014) and the geological (Nachtergaele et al., 2002) and geomorphological (Bennard, 2012) context of the area. There is further agreement that these naturally occurring conditions are prime for gully erosion but are exacerbated by anthropogenic factors such as land-use change and degradation (Van der Veen, 2010). Each of these occurrences act as push factors in causing gully erosion (Egboka et al., 1990).

The study area is located in south-east Nigeria between $708^{\prime} \mathrm{N} 60$ 34'E and 40 49'N 80 15'E covering a land area of approximately $57,758.034 \mathrm{Km}^{2}$, as shown in Fig. 1 and 2. It is characterised by coexisting types of land use and land cover, which are mainly affected by gully erosion.

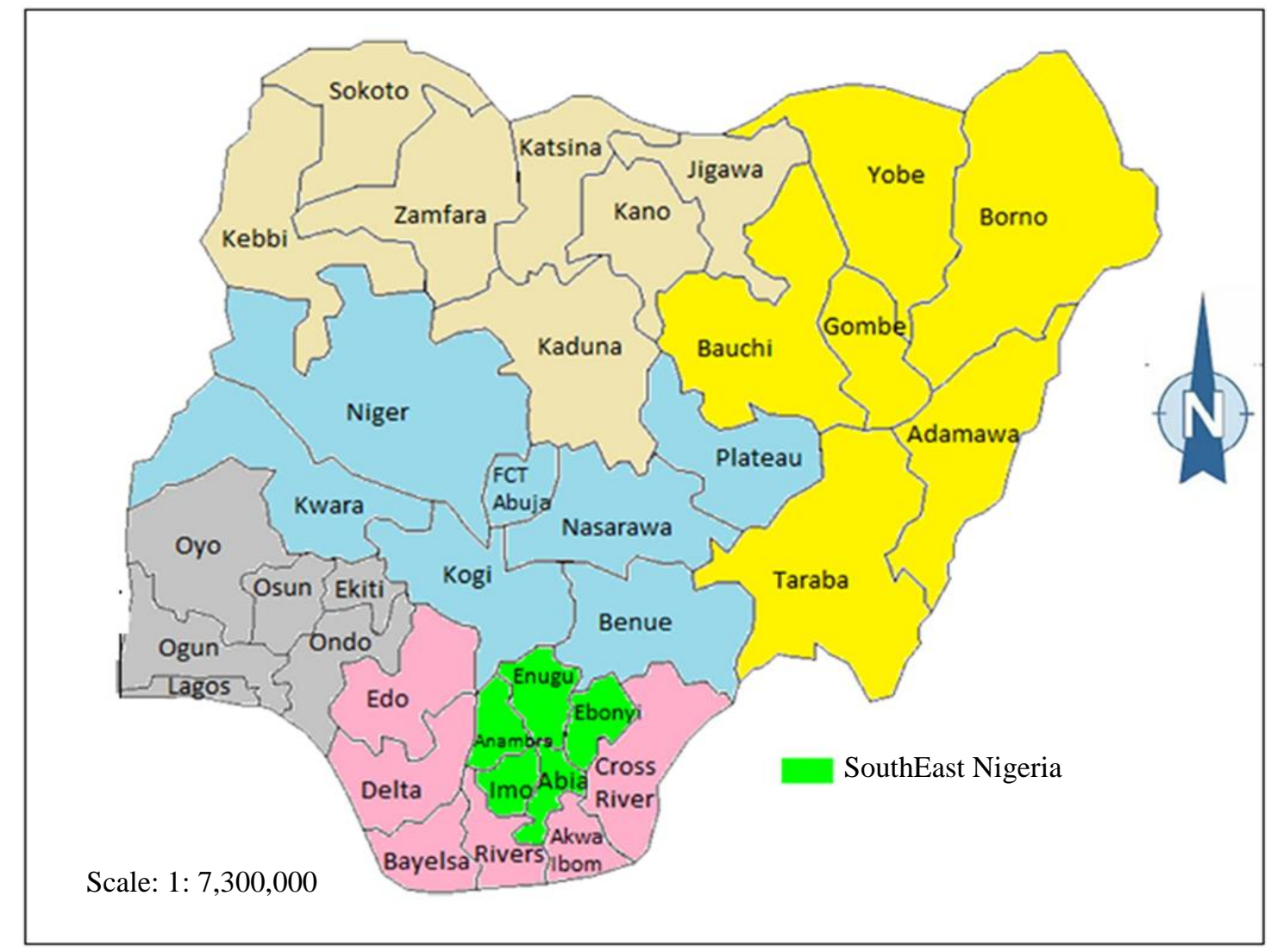

Fig. 1: Nigeria highlighted within the continent of Africa. Study area outlined for context (Iloeje, 2010) 


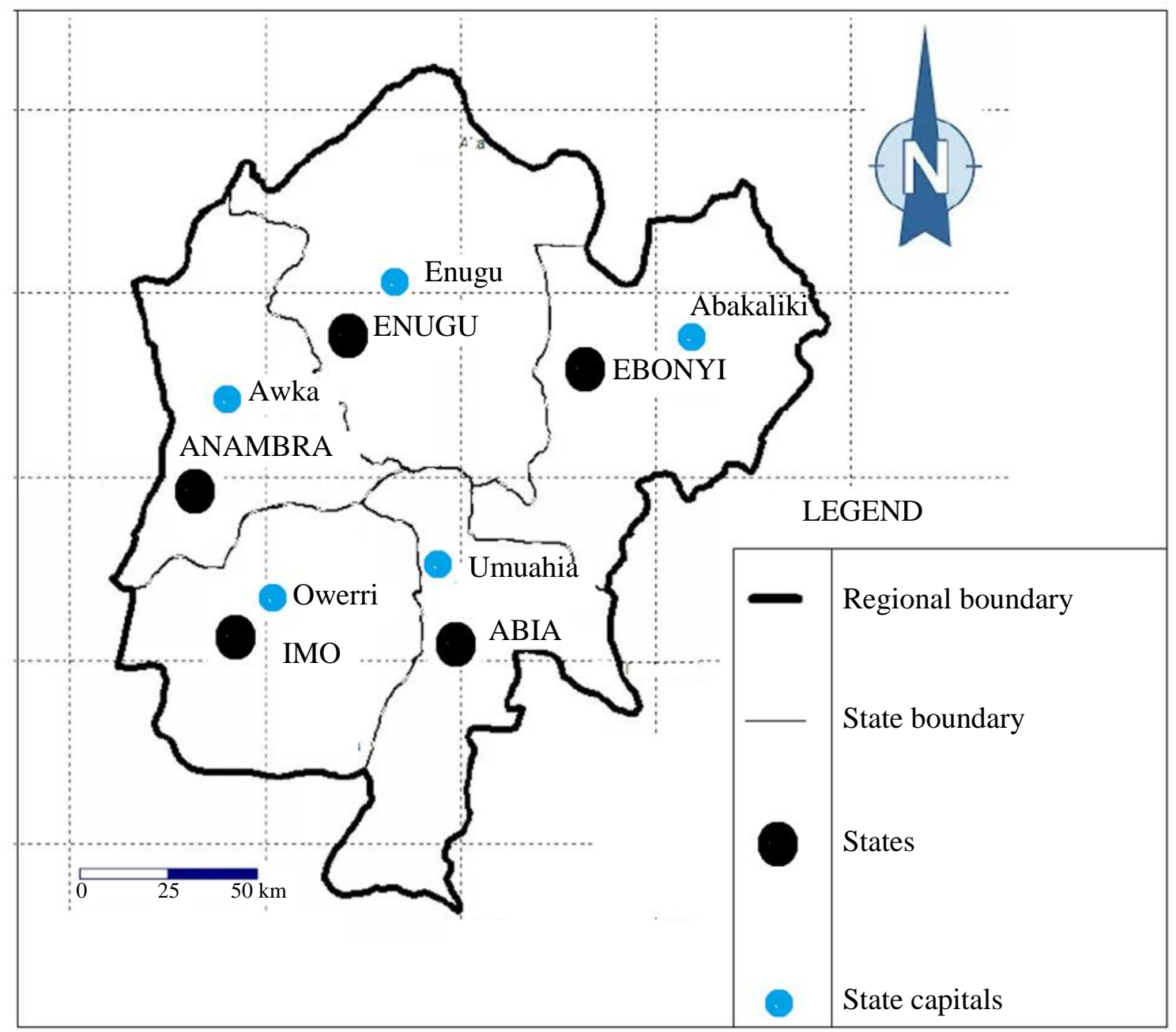

Fig. 2: Map of south-east Nigeria showing the states and their capitals (Iloeje, 2010)

\section{Methodology}

\section{The Methodology Workflow Chart}

This study adopts remote sensing and GIS methodologies in processing the satellite data. This involves Landcover classification, study area DEM analysis, gully area analysis and Analysis of forest degradation and deforestation of the study area (Fig. 3).

In the case of this study, the remote sensing data used in this research were acquired from Landsat images from December 1986, 1987, 1988, 1989, 1990, 1991, 1992, 1993, 2000, 2001, 2004, 2005, 2006, 2007, 2008, 2009, 2010, 2011, 2012 and 2013, 2014 and 2015. Attempts to compile a complete annual data set were impeded by unavailability of Landsat images in the study area from 1994-1999. During this time period the data was not available, not because of cloud cover, but because of data acquisition issues within this period. The study area is found in the tropical region where the presence of cloud cover is extremely common throughout the year (Iloeje, 2010). Images were then chosen from the month of December during the Dry season when the sky is mostly cloud free. The use of Landsat is warranted for several reasons. It is observed that no other current or planned remote sensing system, public or private, fills the role of Landsat in global, regional environmental change research, or in civil and commercial applications (NASA, 1999). The Landsat archive contains data spanning over 40 years (Lee and Liu, 2006) and continues to be collected through Landsat 8 launched in February 2013.

\section{SRTM (DEM) for Topographical Outlook of the Study Area}

In order to obtain the structure and contribution of topography to the development of gullies in the study area. The DEM were downloaded and cropped to the area of interest. The elevation values range from low $=-11 \mathrm{~m}$ to high $=516 \mathrm{~m}$. This elevation data from 
each of the 14 studied gullies which includes hill shade, slope gradient, slope aspect, slope curvature, contour of the area, cross profile and gully stream order, represent an independent variable for use in further statistical analysis to determine its influence on gully formation and erosion rates. These DEM rasters used in this analysis were processed and calculated with spatial analyst tools of GIS software (ArcGIS, Erdas Imaging etc).

\section{Google Earth Images for Gully Analysis}

Google Earth images were used in order to aid analysis of gullies hidden from view in the Landsat images due to vegetation cover (Almeer, 2012), weak spectral signatures, or because of the low spatial resolution of the Landsat image compared to the specific images sourced from Google Earth (Martinez-Casasnovas, 2003). Google Earth images were downloaded, and gully edges were digitized using the polygon tool from the Google Earth for digitization and quantification of the gully areas, starting from the first available year, 2006, to 2015 to act as a supporting dataset to the Landsat archive. Some of the gullies that are found in Landsat images are as well found in Google Earth images and they were digitized and measured to compare with Landsat measurement.

\section{Land-Cover Classification of the Study Area}

Land cover classifications were deduced from Landsat and ALOS raster data by ISO Cluster Analysis, a form of unsupervised classification for pixel oriented and supervised for OBIA oriented. These unsupervised and supervised classifications were assisted using the 40 gully points and 60 other land-use points picked during field work. Five classes were chosen to represent the land based on the Land-cover types of the study area. The classes identified were 1. Water, 2. Vegetation, 3. Agriculture, 4. Urban-Land and 5 Gully/Open-Land. Accuracy Assessment was done with Google Earth to extract 100 KLM points from the classified data which gave between 80 to $93 \%$ accuracy. This was checked with the 100 Random points extracted from the classified data; at the location of each random point, a land-cover of that part using Google-Earth was used to compare it with the land-cover of the classified raster. Google-Earth was used because it has better resolution than Landsat image and the features can be better observed (Virginia Geospatial, 2011).

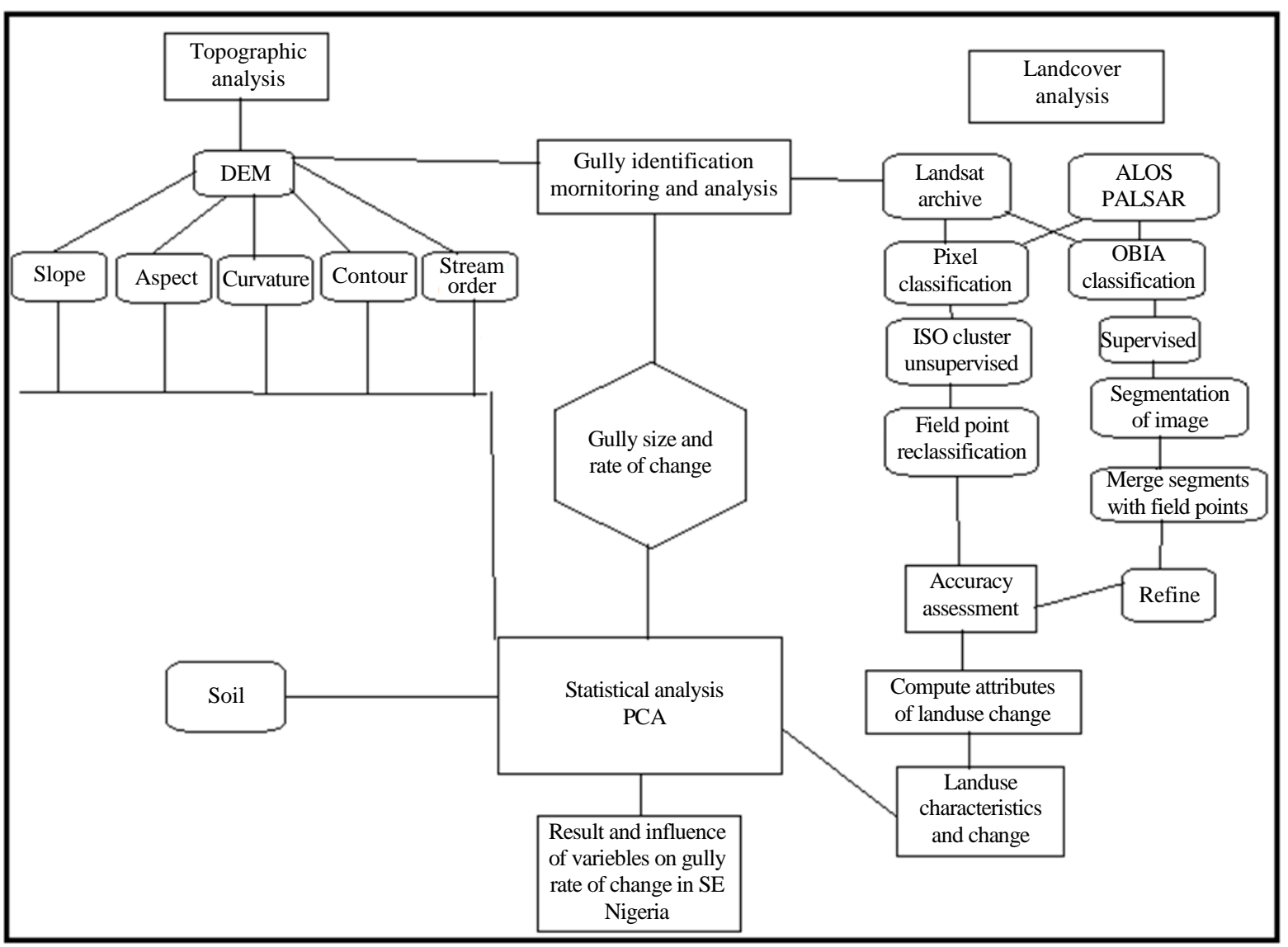

Fig. 3: The methodology workflow chart 
The missing Landsat data from 1994-1999 were obtained by calculating the linear interpolation by connecting two adjacent known values of 1994 and 1999. The Linear Interpolation method used here is shown in Equation (2) to estimate the value of a function between two known values. If the two known values are $\left(x_{1}, y_{1}\right)$ and $\left(x_{2}, y_{2}\right)$, then the $y$ value for some point is:

$$
y=y_{1}+\left(x-x_{1}\right) \frac{y_{2}-y_{1}}{x_{2}-y_{1}}
$$

\section{Presentation of Result}

\section{Regional Topographical Analysis}

Rendering Digital Elevation Models (DEM) to detect changes and calculate gully dimensions of focused gully sites (to observe how slope, nature of slope, aspect and gully stream order influence gully development)". The adoption of Digital Elevation Model for this analysis is a new method that can easily reveal the nature of the landscape. Land surface topography has been reported to significantly affect the processes of runoff and erosion (Zevenbergen and Thorne, 1987). The presentation of the regional topographic analysis in this study looks into the natural causes of gully development in the study area although known to be caused by both the contributions of topographic and anthropogenic disturbances (Lash et al., 1996; Igbokwe et al., 2008). In this section, the analysis of Elevation, slope, curvature of slope, gradient of slope, slope Aspect, stream order generation, contour generation and cross profile of gully sites are presented with a subsection provided to cover the influence of each variable.

\section{Elevation}

The digital elevation map of the study area is produced from the SRTM data at $30 \mathrm{~m}$ (1 Arc-second) resolution. The elevation map of the study area presented has a minimum elevation value of $-11 \mathrm{~m}$ and a maximum of $516 \mathrm{~m}$ ASL. When gully points were overlaid, as can be seen in Appendix I, it reveals that gullies are found on areas that are higher in elevation compared with the surrounding areas. All the 14 surveyed gullies are located on areas with elevation points above $10 \mathrm{~m}$.

\section{Slope}

The slope gradient is one of the most important factors affecting gully erosion (Qing-Quan et al., 2001). Ofomata (2002) also emphasizes the importance of slope by showing that the studied gullies are located at the base of slopes or hills. Igbokwe et al. (2008) observed that in the simplest terms, land located on steep inclines is more vulnerable to water erosion than flat land. The highest elevations in the region are detected at elevations of 516 m. In terms of degrees Appendix II shows that areas with $0^{\circ}-10^{\circ}$ are mostly found in low lying areas which are mainly found on top of plateaux, flood plains, flat areas and areas liable to flooding. Areas with $10^{\circ}-20^{\circ}-30^{\circ}$ and above accommodate most gullies revealing that these areas are where gullies are most commonly developing. The analysis of slope and overlay of gully points have revealed that gullies mainly develop in areas with $10^{\circ}$ and above. Of all the 14 surveyed gullies, 8 gullies $(57 \%)$ are found at $10^{\circ}$ $20^{\circ}$ and 6 gullies $(43 \%)$ at $20^{\circ}$ and above. Appendix II provides a graphic showing slope and elevation.

\section{Slope Aspect}

Further analysis of topography was conducted via analysis of gully locations in respect to the slope aspect. Kosmas et al. (1997) maintained that slope orientation affects gully development which depends on the side that is receiving rainfall more which determines the amount of runoff. The aspect map of the study area, Appendix II, was classified into ten classes, defined as: Flat, N, NE, E, SE, S, SW, W, NW. On this basis, the aspect classes of southeast Nigeria highlight a fairly homogeneous distribution. Slopes facing from North to North-west slightly predominate when compared with South, South-east and south-west while the value of -1 is used to identify flat surfaces such as flood plains, fluvial terraces, river courses and hill plains. None of the gullies were located on areas with value of -1 which represent a flat area.

\section{Slope Plan Curvature}

This section also looks at slope plan curvature as part of topography that influences gully development in the study area and answers part of objective 3 above. The slope geometry of hill sides whether convex or concave often contribute significantly to soil loss and gully development. Poesen et al. (2003), in working on gully erosion and environmental change in Leuven, Belgium, recorded that uplands act as a link through which run-off transports sediments down the hill, contributing to the development of gullies. Zapp and Nearing agreed that Slope shape has a significant impact on rill patterns and gully developemt. The curvature is very important in understanding how run-off flows in the study area, which influences gully erosion and deposition. The low values of $-5\left(\times 10^{6}\right)$ of plan curvatures define convexity; while high values of $6\left(\times 10^{6}\right)$ plan curvatures characterize concavity of slope curvature. Values of plan curvatures around zero indicate that the surface is flat.

\section{Gradient of the Slope}

The slope gradient is one of the most important factors affecting gully erosion. Under the same rainfall runoff, gully erosion could be drastically different on different slope gradient (Qing-Quan et al., 2001). Igwe (2004) maintained that as surface water continues to flow, it starts 
to remove the cementing materials of the soil through the fissures, which develop into gullies depending on the nature and gradient of the slope. In the analysis of geographical gradient of the slope of the 14 test gully sites, the data reveals that they have different gradient values. The Iyioku, Okigwe, Igboukwu, Njaba, Orlu, Amucha, Ngwo1, Ngwo2, Oguta, Umuahia, Isinweke, Nekede, Urualla and Nawfia gully sites are shown in Table 1 . The contours at the head of the 14 gully sites were higher than those at the lower end of the gully sites. The average gradient of the 14 studied gullies is 1 in $28.6 \mathrm{~m}$.

This is represented on the gradient chart Fig. 4 showing individual gullies.

\section{Local Soil}

Some environmental Scientists have attributed soil as the main influence on gully development, (Lash et al., 1996; Wisner et al., 2004). Lash et al. (1996), attribute gully erosion to physical factors, but suggest that its severity is greatly influenced by the structure and texture of the prevalent soil. Ofomata (2008; Onwumerobi,
2002; Igwe, 2004) recommended soil as a strong factor in gully erosion development of southeast Nigeria.

Taking a look on the analysis from Table 1, it reveals that even though the soils appear to have similar characteristics, the gradient of the gullies tends to be lower in areas where there are Ferralic-Arenosol soils (mean gradient $=1$ in 37.7); rather than Gleysols and Fluvisols (mean gradient $=1$ in 24). Ferralic-Arenosols soils; Gleysols and Fluvisols have deeper weathering and also unconsolidated sandy sediments (Akanwa, 2017). Gleysols and Fluvisols have loose sandy sediments and have similar characteristics with Red Ferralsols and Hydromorphic soils but their weathered soil is not as deep as Ferralic-Arenosols and Feralsols and Nitosols soils (Akanwa, 2017). All these physical factors are highly influenced by anthropogenic factors (Igwe, 2004). In the location of the 14 gullies 8 gullies are located on (Ferralic and Arenosols), 3 gullies are located on (Feralsols and Nitosols) and 3 gullies are located on (Gleysols and Fluvisols). Which is represented by 57, 21 and $21 \%$ of the number of gullies respectively.

Table 1: Calculated gradient of gullies for the 14 specific gullies and Soil types are shown

\begin{tabular}{|c|c|c|c|c|c|c|c|}
\hline & Gully Name & $\begin{array}{l}\text { Maximum } \\
\text { Elevation (m) }\end{array}$ & $\begin{array}{l}\text { Minimum } \\
\text { Elevation (m) }\end{array}$ & $\begin{array}{l}\text { Horizontal } \\
\text { Difference (m) }\end{array}$ & $\begin{array}{l}\text { Distance } \\
(\mathrm{m})\end{array}$ & Gradient $(\mathrm{m})$ & Soil Type found \\
\hline 1 & Iyioku & 250 & 150 & 100 & 6618 & 1 in 66 & Gleysols and Fluvisols \\
\hline 2 & Okigwe & 150 & 75 & 75 & 7405 & 1 in 99 & Ferralic-Arenosols soils \\
\hline 3 & Njaba & 250 & 175 & 75 & 945 & 1 in 13 & Feralsols and Nitosols \\
\hline 4 & Igboukwu & 250 & 175 & 75 & 905 & 1 in 12 & Ferralic-Arenosols soils \\
\hline 5 & Orlu & 100 & 75 & 25 & 107 & 1 in 4 & Feralsols and Nitosols \\
\hline 6 & Amucha & 175 & 100 & 75 & 356 & 1 in 5 & Ferralic-Arenosols soils \\
\hline 7 & Ngwo-1 & 175 & 100 & 75 & 250 & 1 in 3 & Ferralic-Arenosols soils \\
\hline 8 & Oguta & 100 & 50 & 50 & 2280 & 1 in 46 & Gleysols and Fluvisols \\
\hline 9 & Umuahia & 125 & 50 & 75 & 115 & 1 in 2 & Feralsols and Nitosols \\
\hline 10 & Isinweke & 100 & 50 & 50 & 2120 & 1 in 42 & Ferralic-Arenosols soils \\
\hline 11 & Nekede & 100 & 25 & 75 & 2031 & 1 in 27 & Ferralic-Arenosols soils \\
\hline 12 & Ngwo-2 & 150 & 50 & 100 & 175 & 1 in 2 & Gleysols and Fluvisols \\
\hline 13 & Urualla & 250 & 50 & 200 & 8039 & 1 in 40 & Ferralic-Arenosols soils \\
\hline 14 & Nawfia & 150 & 75 & 75 & 2999 & 1 in 40 & Ferralic-Arenosols soils \\
\hline
\end{tabular}

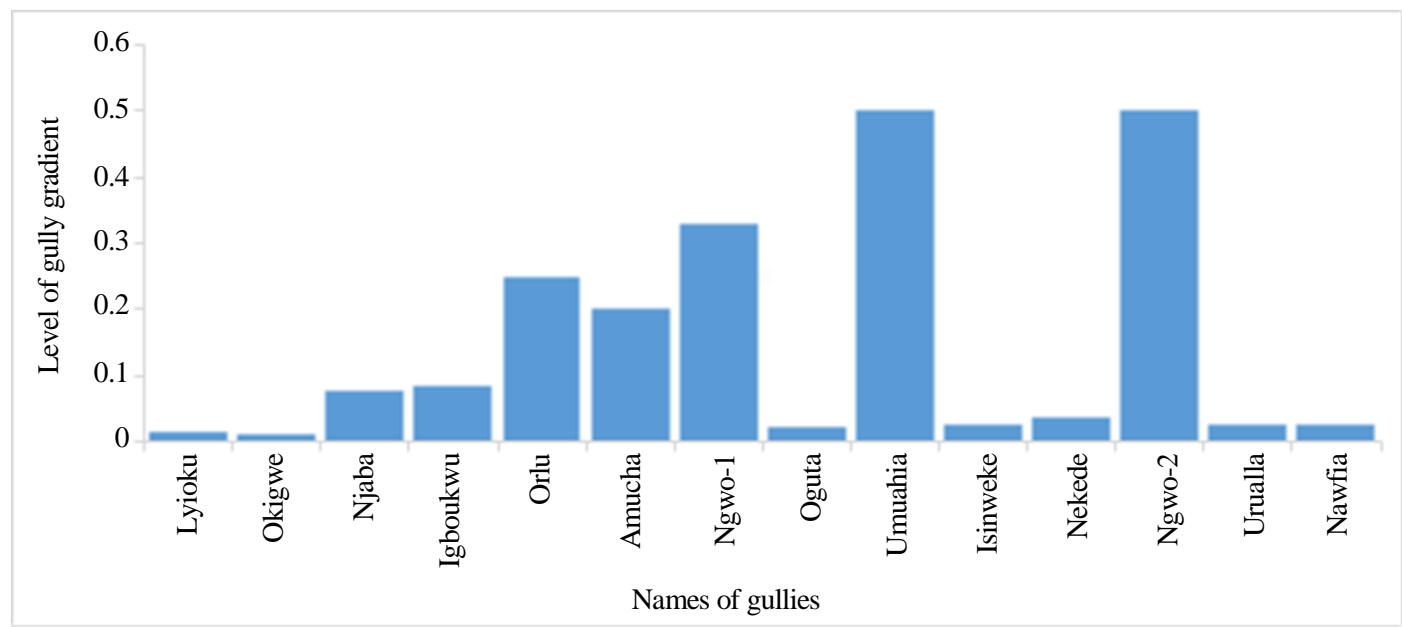

Fig. 4: Chart using the gradient data of the 14 gullies by category 


\section{Gully Strahler Stream Order}

The studied gullies are found at the segment of the drainage which has mostly the hierarchy of tributary number $1,2,3$ and 4 . Showing that 1 and 2 contribute to 3 while 1,2 and 3 contribute to 4 which produce high runoff. The hierarchy of 1,2,3 and 4 show that the gully sites are located at slope areas with high runoff. The cells that have 5 and above are surface water. The 14 gullies are located thus; hierarchy 1 (6 gullies), hierachy 2 (5 gullies), hierachy 3 (1 gully) and 4 (3 gullies). The 14 gullies are represented by $1,2,3$ and 4 hierachy as 43 , 36, 7 and $14 \%$ respectively Appendix V.

\section{Regional Land Cover Classification}

This section used remote sensing data (Landsat and ALOS PALSAR) to determine change in land-cover through Pixel based and Object Based Image Analysis (OBIA) classification over a maximum 30-year period (1986-2015) in SE Nigeria". The classification methods for this purpose will be compared and contrasted" There acceptability were based on the accuracy assessment in Table 5 and 6. Many researchers have attributed landcover removal as the main source of gully development. In South East Nigeria, (Igwe, 2004; Onyekwere, 2001; Ijeoma and Okey, 2005) have separately agreed that gullies mostly develop on soil on which vegetal growth has been disturbed due to infrastructural developments, for example roads and housing developments. Land cover classification is one of the modern methods of ascertaining the level of land cover removal by human interference.

Pixel and Object Based Image Analysis (OBIA) land cover classification is conducted for the study region. Data is provided for each individual year within the defined study period. The regional study area measures approximately $57,758.034 \mathrm{~km}^{2}$. According to the two different classification methodologies, the results reveal that the vegetated land surface, at the beginning of the study in the year 1986, comprises 90 and $83 \%$ of the study area for Pixel and Object Based classification methods respectively. These values highlight the original dense canopy coverage of the region. By 2015, over a period of almost 30 years, this classified vegetated proportion of the total land surface has reduced to $35 \%$ according to Pixel based approaches and $41 \%$ for OBIA classification. According to both independent methodologies this highlights a significant loss in vegetated land surface. Losses of vegetated area are estimated at 55 and $41 \%$ of the total studied area, for Pixel and OBIA classification respectively, between 1986-2015. With respect to the regional land cover classification presented in Table 2 and 3 for each of the available study years, the significant loss in vegetation is predominantly attributable to increases in Urban-land and Agriculture. As well as appearing to contribute to a loss in vegetation these increases in urban and agricultural areas appear to have influenced the existence and development of Gully/Open-land formation in the study area. While a $55 \%$ reduction in vegetated land has been detected over the study period, other land use classes exhibit increases. The increases exhibited for the other classifications are $38 \%$ (Urban), $13 \%$ (Gully) $0.4 \%$ (Water) and 3.6\% (Agriculture) according to pixel-based classification, Table 2 . For the $41 \%$ reduction in vegetated land evident using OBIA classification over the study period, these classes account for increases of 31\% (Urban), $10 \%$ (Gully), 0\% (Water), 0\% (Agriculture) Table 3. Both classification methods evidence the significant correlated increases of urban land cover and gully size.

\section{Land-Cover Classification using ALOS PALSAR L- Band}

In comparing the results of Landsat and ALOS PALSAR images of 2008 and 2009, they present similar trends with the exception of water class which increased when compared with Landsat images, Table 4. Also, showing that SAR differentiated water from other classes better than Landsat, may be because of the resolution which is higher than Landsat but more likely through the spectacular scattering resulting in zero backscatter to the SAR sensor.

Table 2: Pixel based classification result as percentage of total area classified. Total area size $=0.57,758.034 \mathrm{~km}^{2}$

\begin{tabular}{|c|c|c|c|c|c|c|c|c|c|c|c|c|c|}
\hline & Classes & ' $86 \%$ & '87\% & ' $88 \%$ & '89\% & '90\% & '91\% & '92\% & '93\% & ${ }^{\prime} 00 \%$ & ' $01 \%$ & ' $02 \%$ & ' $03 \%$ \\
\hline 1 & Water & 0.6 & 0.8 & 2 & 0.9 & 0.9 & 1 & 1 & 2.5 & 1 & 1 & 0.8 & 1 \\
\hline 2 & Vegetation & 90 & 90 & 76 & 75 & 72 & 70 & 64 & 62 & 59 & 59 & 57 & 52 \\
\hline 3 & Agriculture & 5.4 & 5.2 & 11 & 11 & 12 & 14 & 13 & 12.5 & 12 & 11 & 11.2 & 13 \\
\hline 4 & Urban-Lands & 2 & 2 & 8 & 9 & 10.1 & 10 & 15 & 16 & 17 & 18 & 20 & 22 \\
\hline \multirow[t]{2}{*}{5} & Gully/openland & 2 & 2 & 3 & 4 & 5 & 5 & 7 & 7 & 11 & 11 & 11 & 12 \\
\hline & & '04\% & $' 05 \%$ & '06\% & $' 07 \%$ & '08\% & $' 09 \%$ & $' 10 \%$ & $' 11 \%$ & $' 12 \%$ & ' $13 \%$ & ' $14 \%$ & ' $15 \%$ \\
\hline 1 & Water & 1 & 3 & 1 & 1 & 3 & 2 & 3 & 3 & 3 & 1 & 1 & 1 \\
\hline 2 & Vegetation & 52 & 51 & 49 & 44 & 44 & 43 & 42 & 43 & 41 & 38 & 37 & 35 \\
\hline 3 & Agriculture & 13 & 10 & 14 & 14 & 10 & 10 & 10 & 9 & 9 & 9 & 9 & 9 \\
\hline 4 & Urban-Lands & 23 & 24 & 25 & 30 & 32 & 33 & 34 & 33 & 35 & 38 & 39 & 40 \\
\hline 5 & Gully/openland & 11 & 12 & 11 & 11 & 11 & 12 & 11 & 12 & 12 & 14 & 14 & 15 \\
\hline
\end{tabular}


Sylvanus Iro / American Journal of Environmental Sciences 2020, 16 (5): 96.111 DOI: 10.3844/ajessp.2020.96.111

Table 3: OBIA classification result as percentage of total area classified. Total area size $=57,758.034 \mathrm{~km}^{2}$

\begin{tabular}{|c|c|c|c|c|c|c|c|c|c|c|c|c|c|}
\hline & Classes & ' $86 \%$ & ' $87 \%$ & ' $88 \%$ & ' $89 \%$ & ‘90\% & '91\% & ‘92\% & '93\% & ‘ $00 \%$ & ' $01 \%$ & ${ }^{\prime} 02 \%$ & '03\% \\
\hline 1 & Water & 1 & 1 & 1 & 1 & 1 & 1 & 2 & 1 & 1 & 2 & 2 & 2 \\
\hline 2 & Vegetation & 83 & 80 & 76 & 75 & 73 & 71 & 71 & 68 & 61 & 59 & 57 & 56 \\
\hline 3 & Agriculture & 7 & 8 & 8 & 8 & 8 & 9 & 6 & 7 & 10 & 10 & 10 & 10 \\
\hline 4 & Urban-lands & 5 & 6 & 9 & 10 & 11 & 12 & 14 & 16 & 19 & 21 & 23 & 24 \\
\hline 5 & Gully/openland & 4 & 5 & 6 & 6 & 6 & 7 & 7 & 8 & 9 & 8 & 8 & 8 \\
\hline & & ' $04 \%$ & ‘ $05 \%$ & $' 06 \%$ & '07\% & '08\% & ‘ $09 \%$ & $' 10 \%$ & ‘ $11 \%$ & $' 12 \%$ & ' $13 \%$ & $' 14 \%$ & ' $15 \%$ \\
\hline 1 & Water & 2 & 2 & 2 & 2 & 2 & 2 & 2 & 2 & 2 & 2 & 1 & 1 \\
\hline 2 & Vegetation & 54 & 50 & 50 & 48 & 48 & 47 & 46 & 46 & 46 & 44 & 44 & 42 \\
\hline 3 & Agriculture & 9 & 9 & 9 & 9 & 8 & 8 & 8 & 8 & 7 & 7 & 7 & 7 \\
\hline 4 & Urban-lands & 26 & 29 & 29 & 30 & 32 & 33 & 33 & 32 & 33 & 34 & 35 & 36 \\
\hline 5 & Gully/openland & 9 & 10 & 10 & 11 & 10 & 10 & 11 & 12 & 12 & 13 & 13 & 14 \\
\hline
\end{tabular}

Table 4: Comparison of Pixel and OBIA land cover classification of ALOS PALSAR and Landsat Images from 2008 and 2009 in terms of $\%$ of regional study area $\left(57,758.034 \mathrm{~km}^{2}\right.$ total area) covered. Difference column shows difference $\%$ values. t-test is conducted with no significant differences detected, as expected given the use of $\%$ values.

\begin{tabular}{|c|c|c|c|c|c|c|c|}
\hline & \multirow[b]{2}{*}{ Classes } & \multicolumn{2}{|c|}{ Pixel (\%) (SAR) } & \multicolumn{2}{|c|}{ Pixel (\%) (Landsat) } & \multicolumn{2}{|c|}{ Difference $(\%)$} \\
\hline & & 2008 & 2009 & 2008 & 2009 & 2008 & 2009 \\
\hline 1 & Water & 4.5 & 5.0 & 3 & 2.5 & 1.5 & 2.5 \\
\hline 2 & Vegetation & 48 & 48 & 44 & 43 & 4 & 5 \\
\hline 3 & Agriculture & 5 & 6.0 & 10 & 10 & -5 & 4 \\
\hline 4 & Urban-Lands & 33 & 34 & 32 & 33 & 1 & 1 \\
\hline \multirow[t]{3}{*}{5} & Gully/openland & 9.5 & 8.5 & 11 & 11.5 & -1.5 & 3 \\
\hline & $\mathrm{P}$ value & \multicolumn{2}{|c|}{ OBIA (\%) (SAR) } & OBIA (\%) (Landsat) & & Difference $(\%)$ & 0.87 \\
\hline & Classes & 2008 & 2009 & 2008 & 2009 & 2008 & 2009 \\
\hline 1 & Water & 3 & 2 & 2 & 2 & 1 & 0 \\
\hline 2 & Vegetation & 49 & 46 & 48 & 47 & 1 & 1 \\
\hline 3 & Agriculture & 6 & 8 & 8 & 8 & 2 & 0 \\
\hline 4 & Urban-Lands & 34 & 32 & 32 & 33 & 2 & 1 \\
\hline \multirow[t]{2}{*}{5} & Gully/openland & 8 & 12 & 10 & 10 & 2 & 2 \\
\hline & $P$ value & & & & & 1 & 1 \\
\hline
\end{tabular}

Table 5: Accuracy assessment matrix for Landsat and ALOS 2008 pixel classification using 2008 imagery

\begin{tabular}{|c|c|c|c|c|c|c|}
\hline 2008 Landsat pixel class & Water & Vegetation & Agric & Urbanland & Gully/openland & Raw total \\
\hline \multicolumn{7}{|l|}{2008 Google Earth Image } \\
\hline Water & 5 & 0 & 0 & 0 & 1 & 6 \\
\hline Vegetation & 0 & 41 & 2 & 1 & 0 & 45 \\
\hline Agric & 0 & 4 & 21 & 0 & 0 & 23 \\
\hline Urbanland & 1 & 1 & 0 & 13 & 0 & 16 \\
\hline Gully/openland & 0 & 0 & 1 & 1 & 8 & 10 \\
\hline Column Total & 6 & 46 & 24 & 15 & 9 & 100 \\
\hline \multicolumn{7}{|c|}{$\begin{array}{l}\text { Overall Accuracy }=88 / 100=88 \% \\
2008 \text { Google Earth Image }\end{array}$} \\
\hline 2008 ALOS Pixel Class & Water & Vegetation & Agric & Urbanland & Gully/openland & Raw total \\
\hline Water & 5 & 0 & 0 & 0 & 1 & 6 \\
\hline Vegetation & 0 & 42 & 2 & 0 & 0 & 49 \\
\hline Agric & 0 & 3 & 20 & 0 & 0 & 20 \\
\hline Urbanland & 0 & 2 & 0 & 14 & 0 & 15 \\
\hline Gully/openland & 1 & 0 & 1 & 1 & 8 & 10 \\
\hline Column Total & 6 & 47 & 23 & 15 & 9 & 100 \\
\hline Overall Accuracy $=89 / 10$ & & & & & & \\
\hline
\end{tabular}

\section{Gully/Open-Land Classification}

It is evident from the percentage changes that converse to the vegetation loss the Gully/open-land classification has followed a significant and steady increase in area covered over the same time period.
According to pixel-based classification (Table 7a), the Gully/open-land class has increased from a proportionate land cover of $2 \%$ in 1986, to $15 \%$ in 2015 for Pixel and $4 \%$ in 1986 to $14 \%$ in 2015 for OBIA classification. This represents an increase in area size of gully/open lands of 13 and $10 \%$ for Pixel and OBIA classifications 
respectively over 30 years, see Appendix IV (a) and (b). A mean increase of $11.5 \%$.

Table 6: Accuracy assessment matrix for Landsat and ALOS 2008 OBIA classification

\begin{tabular}{lllllll}
\hline 2008 Landsat OBIA Class & Water & Vegetation & Agric & Urbanland & Gully/openland & Raw Total \\
\hline 2008 Google Earth Image & & & & & & \\
Water & 5 & 0 & 0 & 1 & 1 & 6 \\
Vegetation & 0 & 45 & 2 & 1 & 0 & 46 \\
Agric & 0 & 0 & 21 & 0 & 0 & 22 \\
Urbanland & 0 & 2 & 0 & 13 & 0 & 15 \\
Gully/openland & 0 & 0 & 1 & 1 & 8 & 10 \\
Column Total & 5 & 47 & 24 & 16 & & 100 \\
Overall Accuracy = 91/100 & & & & & \\
2008 Google Earth Image & & & & & \\
2008 ALOS OBIA Class & Water & Vegetation & Agric & Urbanland & Gully/openland & Raw Total \\
Water & 5 & 0 & 0 & 0 & 0 & 6 \\
Vegetation & 0 & 45 & 1 & 1 & 0 & 49 \\
Agric & 0 & 2 & 19 & 0 & 0 & 20 \\
Urbanland & 0 & 2 & 0 & 14 & 1 & 15 \\
Gully/openland & 0 & 0 & 1 & 16 & 9 & 100 \\
Column Total & 5 & 49 & 21 & &
\end{tabular}

Table 7: (a): Calculated pixel classification-based Area (pixel count) and \% covered by Gully/Openland class from 1986-2015 (red = interpolated). ( $\mathrm{red}=$ interpolated). Single pixel is equal to $900 \mathrm{~m}^{2}\left(57,758.034 \mathrm{~km}^{2}\right.$ total area)

\begin{tabular}{llclll}
\hline Years & Gully/openland pixel count & \% of Area covered & Years & Gully/openland pixel count & \% of Area covered \\
\hline 1986 & 1012176 & 2 & 2001 & 5616757 & 11 \\
1987 & 1012176 & 2 & 2002 & 5417067 & 11 \\
1988 & 1715029 & 3 & 2003 & 5741335 & 12 \\
1989 & 2210168 & 4 & 2004 & 5017688 & 11 \\
1990 & 2804669 & 5 & 2005 & 6389870 & 12 \\
1991 & 3200445 & 5 & 2006 & 7296029 & 11 \\
1992 & 3993673 & 7 & 2007 & 7423424 & 11 \\
1993 & 4790330 & 7 & 2008 & 6301827 & 11 \\
1994 & 4857860 & 7 & 2009 & 8024697 & 12 \\
1995 & 4966274 & 7 & 2010 & 7999151 & 11 \\
1996 & 5030673 & 8 & 2011 & 7367368 & 12 \\
1997 & 5132196 & 8 & 2012 & 8064697 & 14 \\
1998 & 5115838 & 8 & 2013 & 9276909 & 14 \\
1999 & 5297842 & 8 & 2014 & 9686547 & 15 \\
2000 & 5263041 & 11 & 2015 & 9986433 &
\end{tabular}

Table 7: (b): Calculated OBIA classification-based Area (pixel count) and \% covered by Gully/Openland class from 1986-2015 (red $=$ interpolated). Single pixel is equal to $900 \mathrm{~m}^{2}\left(57,758.034 \mathrm{~km}^{2}\right.$ total area)

\begin{tabular}{lllllc}
\hline Years & Gully/openland pixel count & \% of Area covered & Years & Gully/openland pixel count & \% of Area covered \\
\hline 1986 & 2653360 & 4 & 2001 & 5344361 & 8 \\
1987 & 3679894 & 5 & 2002 & 5567043 & 8 \\
1988 & 3849040 & 6 & 2003 & 5938179 & 8 \\
1989 & 4124799 & 6 & 2004 & 6012407 & 9 \\
1990 & 4308708 & 6 & 2005 & 6680451 & 10 \\
1991 & 4676316 & 7 & 2006 & 6682816 & 10 \\
1992 & 4676526 & 7 & 2007 & 7348497 & 11 \\
1993 & 5344361 & 8 & 2008 & 5344361 & 10 \\
1994 & 5439796 & 8 & 2009 & 5344388 & 11 \\
1995 & 5426162 & 8 & 2010 & 7279418 & 11 \\
1996 & 5446288 & 8 & 2011 & 8016542 & 12 \\
1997 & 5516558 & 8 & 2012 & 8016752 & 12 \\
1998 & 5587394 & 8 & 2013 & 8684587 & 13 \\
1999 & 5743545 & 9 & 2014 & 8999346 & 13 \\
2000 & 6012406 & 9 & 2015 & 9074653 & 14 \\
\hline
\end{tabular}


The absolute values of area covered by the Gully/Openland class are shown in Table $7 \mathrm{a}$ and $7 \mathrm{~b}$ for Pixel and OBIA classification respectively. According to the Pixel classification an increase of 8974257-pixel count is exhibited during the study period. This equates to a mean annual increase of 299141.9 per year across the region. For the OBIA classification the value is 214043.1 per year Performing a simple two sample t test of difference between the two groups of data show that there is no significant difference between the two classification methods and their accounts of the gully/openland class $(\mathrm{p}=<0.05)$.

\section{Principal Component Analysis}

This approach was applied in this study to demonstrate the reactions of the variables and their contributions to gully formation and development of the study area. The main purpose of principal component analysis in this study is to obtain a minimal number of independent linear combinations. PCA was identified as an appropriate statistical tool to determine the influence of gully factors on gully development, relationships of gully factors and the effects of these gully factors.

The results of the Principal Component Analysis will help to know the weight and relationship of the gully variables. PCA has been used in this manner in studies such as (Yu et al., 1998; Vajcnerova et al., 2011). In a similar way this will be conducted here. The strategy to testing outlined in this section is as follows:

- PCA (a) (Variables used 2015 Gully area, 2014/2015 yearly gully change in metre squared per square metre, 2014/2015 Vegetation Loss, Soil, Slope in degrees, Gully stream order and Elevation

- $\quad$ PCA (b) (Variables used 2010 Gully area, 2009/2010 yearly gully change in metre squared per square metre, 2009/2010 Vegetation Loss, Soil, Slope in degrees, Gully stream order and Elevation

- PCA (c) (Variables used 2006 Gully area, $2006 / 2007$ yearly gully change in metre squared per square metre, 2006/2007 Vegetation Loss, Soil, Slope in degrees, Gully stream order and Elevation

In each case, 7 gully variables are examined across the 14 gully sites. With the yearly gully change in metre squared per square metre the focus. The aim of this PCA is to identify the variables that are closely associated with the rate of change of the gullies using the first two components in this analysis. The expectation is that gully variables like vegetation loss, soil and gully stream order have a strong impact on the initiation of gully development and yearly gully change in metre squared per square metre in the study area. Again, some researchers such as (Ayanlade and Drake, 2016; Odemerho and Sada, 2002; Ofomata, 2008) have mentioned these environmental variables as being outstanding in gully development and rate of gully change in southeast Nigeria.

This analysis conducted in this section is for the years $2006 / 2007,2009 / 2010$ and $2014 / 2015$. The purpose is to properly ascertain if the weight and relationship of the variables are similar in these years with regard to year 2014/2015. The years were chosen because from the analysed satellite imageries of the study area, all the gullies have developed by 2006/2007 except some gullies like Nawfia gully which developed after 2007. Again, 2009/10 was used to check the results between $2006 / 2007$ and 2014/15 the last year of the study. Principal Component Analysis of the Time Period 2014/15; 2009/10 and 2006/2007.

Principal Component Analysis (PCA) was identified as an appropriate statistical tool to determine the influence of gully factors on gully development, relationships of gully factors and the effects of these gully factors. Using the 7 available variables the normalized data of vegetation loss, slope, soil, elevation, gully stream order, gully area and 2014/2015 gully rate of change per $\mathrm{m}^{2}$ were used.

\section{Comparison of PCA Analysis of 2014/2015, 2009/2010 and 2006/2007 Variables}

From Table 8, Principal Component 1 (PC1) shows that some of the variables appeared with high explanation of variance in 2014/2015 also repeated the same feat in $2009 / 2010$ but to a lesser extent in $2006 / 2007$. For example, Vegetation loss (37, 29\% respectively and with reduced variance in 2006/07 of $7 \%$ but appeared stronger in PC2 with 59\%). Soil (46, 47 and $51 \%$ respectively), but Soil performed poorly in PC2 variance of all the years. Gully stream order (44, 43 and $45 \%$ ) respectively, in PC2, Gully stream order equally repeated the same feat with variance of $32,-32$ and $-27 \%$ respectively. Gully area $(48,-50$ and $-53 \%)$ respectively, but PC2 results for 2014/15, 2009/2010 and 2006/07 all produced weak variance. yearly gully change in metre squared per square metre was explained in the three time periods to the values of 25,30 and $20 \%$ for $2014 / 15$, 2009/10 and 2006/07 respectively. Slope has 41, 47 and $51 \%$ respectively. Elevation produced weak variance throughout PC1 of the years 6,7 and $7 \%$ respectively, but was strong in the PC2 of all the years $-83,82$ and $50 \%$ respectively.

It can be noticed that all the variables identified to have their variance explained to a high level by PC1 2014/2015, 2009/10 and 2006/2007, appeared to be weak in PC2 of all the years. Those that appeared strongly in PC2, appeared with weak variance in PC1 of all the years, with an exception of Gully stream order that has high variance throughout the years, showing how consistent its influence is on gully development. 
Table 8: Comparison of Component Score Coefficient Matrix (for 2014/15, 2009/10 and 2006/07 of the 7 variables from PCA component Score Coefficient Matrix of data output. The PC1 has eigenvalue of 3.5681 in 2014/2015, 3.5099 in 2009/2010 and 3.1065 in 2006/2007 respectively.)

\begin{tabular}{|c|c|c|c|c|c|c|}
\hline \multirow[b]{2}{*}{ Components } & \multicolumn{2}{|c|}{$2014 / 2015$} & \multicolumn{2}{|c|}{$2009 / 2010$} & \multicolumn{2}{|c|}{$2006 / 2007$} \\
\hline & 1 & 2 & 1 & 2 & 1 & 2 \\
\hline Vegetation Loss & 0.367 & -0.118 & 0.292 & 0.329 & -0.072 & 0.588 \\
\hline Slope & 0.410 & 0.143 & 0.408 & -0.224 & 0.449 & -0.308 \\
\hline Soil & 0.461 & -0.155 & 0.470 & 0.084 & 0.510 & 0.151 \\
\hline Elevation & 0.055 & -0.827 & 0.068 & 0.818 & 0.068 & 0.500 \\
\hline GullyStreamOrder & 0.438 & 0.323 & 0.428 & -0.316 & 0.456 & -0.270 \\
\hline Gully_Area & -0.476 & 0.245 & -0.500 & -0.181 & -0.528 & -0.204 \\
\hline yearly gully change & 0.252 & 0.305 & 0.300 & -0.182 & 0.205 & 0.415 \\
\hline
\end{tabular}

The same environmental variables operational in 2014/2015 appear to have been the major gully factors responsible for gully development and yearly gully change in metre squared per square metre in the study area for the overall encompassing time period although the influence of vegetation loss was less significant in $2006 / 7$. From the biplot of 2014/15, 2009/2010 and $2006 / 07$, two large gullies dominate the effect of gully area, these are the Iyioku and Igboukwu, Okigwe and Oguta and only Iyioku gully for 2006/2007. These gullies appear to behave in a different fashion to the other studied gullies. This is evident by looking at the Score plots for the three time periods when excluding these gullies. Also, from the biplots all the gullies, they continually appear to be dominated by all the variables. There is no need removing the less significant ones to rerun the PCA model again since all the variables entered in all the years appeared strongly in either PC1 or PC2 or both. The reason for all these will be discussed more in the discussion section of the study.

\section{Discussion}

\section{Vegetation Loss as a Precursor to Gully Development}

Vegetation loss was evident across the study region as identified by this study Tables 2 and 3. This appears to follow a global trend with gully development responding to vegetation losses similar to those posed by (Prosser and Slade, 1994; Ahmed and Dinye, 2012), in both southern Australia and in Kumasi, Ghana, respectively. In all these cases reduced vegetation cover made the area susceptible to widespread rapid gully formation. Based on the land cover classification analyses the steady reduction in vegetation clearly revealed a significant correlation with increases in open land and gully development. The large-scale study by (Ahmed and Dinye, 2012) observed that forest area expansion is being enacted in Europe, North America, the Caribbean, East Asia and Western-Central Asia, but continues to decline in Central America, South America, South and Southeast Asia and all regions in Africa. It is pointed out by (Igwe, 2004) that in South East Nigeria gullies mostly develop on soil on which vegetal growth has been disturbed. This is evidenced on the correlation of gully area sizes and vegetation area which shows very strong correlation. Looking at PCA of year 2014/15 and 2009/2010, vegetation loss appears to have a good variance explained by the Principle Component of $37 \%$ (PC1) and 29\% (PC1) for the respective years. The percent variance of vegetation loss explained is almost similar to that for yearly gully change in metre squared per square metre in the corresponding years of 25 and $31 \%$, could help to drive home the importance of vegetation loss in gully development, although for 2006/2007 these similarities weren't as apparent. The results correspond with those of (Onyekwere, 2001; Ijeoma and Okey, 2005); that used different methodology of interview and site measurement to observe that vegetation loss was a big factor in gully area development in southeast Nigeria. For each year, the gully area variable is correlated with high vegetation loss associated more with smaller gullies which fits the model of vegetation loss acting as an initial driver rather than the key variable driving advanced behaviour.

\section{Topographical Influences on Gully Development}

Topography has a strong influence on gully development. Several studies have identified topography as the main link to gully development. Poesen et al. (2003; Marquisee, 2010; Boardman, 2006; Bochet and García-Fayos, 2004; Igbokwe et al., 2008) observed that topographical influence was the prime reason for gully development in different locations. Some of the topographical factors include the contribution to runoff as the amount and intensity of rainfall combines with these. In southeast Nigeria, rainfall data is high because it is influenced by tropical monsoon climate which generates over $1000 \mathrm{~mm}$ of monthly rainfall every year during rainy season (March-November). The slope of land, properties of soil and the nature and extent of ground cover are all deemed essential contributors to gully formation as reported in (Valentin et al., 2005; Albert et al., 2006). In southeast Nigeria, many works such as (Ofomata, 2002), found that there is a positive 
relationship between relief and gully erosion leading to more pronounced and aggressive gully erosion in areas with valley topography than areas with flat land. This is expected due to the physics of the scenario. Ofomata pointed out that in areas like Agulu-Nanka, Njaba, Nekede-Owerri, Iyioku, Okigwe, Afikpo, Ohafia and Umuahia, the gullies can be traced to the natural slope of the topography but the occurrence of gullies must be influenced by more than just this, otherwise gullies would form on all steep topography. The result of this study tends to agree with Ofomata on the importance of slope by showing that the studied gullies are located at the base of slopes or hills. For example, the slope degree of Iyioku, Okigwe, Umuahia and Nekede are $15^{\circ}, 11^{\circ}$, $10^{\circ}$ and $10^{\circ}$ respectively. with the gullies evidently developing at the base of the slope because it is the area where runoff converges to form the gully head before it develops. PCA and Cluster analysis conducted here shows there is high variance and clustering between the actual magnitude of slope and the proportional yearly gully change in metre squared per square metre, indicating that the gully specific metrics are largely independent of the slope. This study therefore indicates the importance of slope but only to the extent that it exists for a gully to form. This is further supported by the existence of the slope and other variables clustering well with yearly gully change in metre squared per square metre for each year considered.

\section{Nature of Gully Development on Slope}

One of the objectives of this study is to generate Digital Elevation Models (DEM) to detect changes and calculate gully dimensions (including slope) of focused gully sites. The South East Nigeria study area is characterized by gentle to steep slopes with extreme slopes also found in certain areas where $20^{\circ}$ inclines are exhibited. Slope areas less than $20^{\circ}$ are seen in gentle slope and flat areas including river courses, flood plains and hilltop areas. Areas classified to have slope of $10^{\circ}$ and greater, are expected to favour erosion activities based on (Igbokwe et al., 2008). The theory suggests correctly that the greater kinetic energy is gained at the plane with the highest slope angles, but the data presented here suggests that this is not as important a driver as theorised. The revelation from this study shows that most of the gullies develop at the base of the slope for example Iyioku and Njaba gullies with slope areas of $15^{\circ}$ and $9^{\circ}$ respectively have their upper part of the slope ahead of them with areas ranging from $35^{\circ}$ to $40^{\circ}$ at 30 $\mathrm{m}$ resolution. The energy increases down the slope as they converge from lower stream order to higher stream orders at the slope base while carrying eroded materials from deep incisions made at those points. Slope has an effect on run-off and drainage therefore having a profound influence on the moisture regime of the soil.
Studies such as (Poesen et al., 2003; Bennard, 2012) have observed that slope generates the runoff that causes gully erosion. These studies were of the opinion that valley topography is also an underlying factor in gully generation, with steeper and longer slopes providing the higher erosion risk. This theory is not debated here but it is strongly proposed that other factors need to be in place before such erosion can occur; the prime driver proposed here being the loss of vegetation. In South-East Nigeria, (Ofomata, 2002; Iwu, 2012; Abdulfatai et al., 2014; Ekanade et al., 2008; Nwilo et al., 2011; Chikwe, 2012) all agreed that, most developed gullies can be traced to the natural slope of the topography with slope inclinations ascertained to be greater than $8^{\circ}$ encouraging gully erosion. This theory fits more seamlessly with the results exhibited here where all gullies were seen to occur on slopes of at least $5^{\circ}$.

$95 \%$ of the gully erosion sites examined in south-east Nigeria, as part of this study, develop down the hill side areas, determined initially from field visits and through the overlaying of gully points on calculated slope maps. Gully sites such as Iyioku, Okigwe, Njaba, Umuahia, Ngwo1 and Ngwo2 show that they have developed on slope areas greater than $5^{\circ}$ at $30 \mathrm{~m}$ resolution. The slope analysis has shown that gullies in the study area, amongst other gully factors, anchor their development on the nature of the slope, revealing that when every other contributing factor is in place such as vegetation loss, gully stream order and unconsolidated soil, the slope provides the ideal conditions to trigger gully development. Without this characteristic the level of erosion required to form gullies is unlikely to occur. Although not groundbreaking information the multivariate analysis allows the importance of the magnitude of slope to be put in context.

\section{Curvature as an Aspect of Slope in Gully Development}

Slope curvatures were determined in conjunction with slope magnitudes. The curvatures of the study area ranged from -5 plan, defining convexity; to high values of 6 plan characterizing concavity. The relationship between gullies and plan curvatures in south-east Nigeria shows that gully erosion processes commonly occur on concave slopes. Studies by (Gobin et al., 1999) revealed that $60 \%$ of the gullies in southeast Nigeria occur on concave slopes as can be found in Iyioku, Okigwe, Isinweke, Njaba, Ngwo1 and Umuahia, gully sites. In terrain analysis, hill and moderate relief can produce curvatures that vary from -0.5 to 0.5 ; while for mountain, steep, rugged extreme relief, the values can vary between -4 and 4 ESRI, 2015. The nature of the landscape can in part be determined through analysis of these curvatures with negative values typically representing gullies and river courses while positive values are more 
representative of uneroded landscapes (Nwaigwe et al., 2009). This analysis shows that the nature of the topography is in part responsible for gully development in the study area. In the study area for this work the values range between -5 and 6 which signifies a hilly relief, therefore, the surface of the area that is receiving high runoff from hilly areas could be the reason for gully development. The high value of 6 shows that the surface is upwardly concave at more cells (a cell is the area covered on the ground and represented by a single pixel) which contributes to generate accelerated flow and theoretically influence gully development. This helps to explain the development of gullies in the area in combination with other identified factors. This finding is supported by (Beshah, 2003; Bewket and Sterk, 2003; Nwaigwe et al., 2009), where it is observed that the slope geometry of concave hill sides can often contribute significantly to soil loss and gully development. Igbokwe et al. (2008) suggested that Gullies in Okigwe Local Government Area of Imo-State, southeast Nigeria, developed through association with particular slope shapes. That such shapes can be determined accurately from Digital Elevation Models of the area with concave formations in general resulting in more severe gullying. This was observed and concurred in this study. Among other gullies, Okigwe gully developed on concave slope to encourage severe gullying and result in high gully area rate of change. In all the 14 surveyed gullies in the study area, 11 are located on concave while 3 are located on convex slopes evidencing the high proportion.

\section{Influence of Aspect (Slope Direction) on Gully Development}

The Aspect map produced for the South East Nigeria region is dominated by slopes facing $\mathrm{N}$ (337.5-360) to NW (292.5-337.5) Appendix III and evident via the histogram. The gullies are not necessarily conforming to this dominance. The South slopes are intermittently the drier and wetter landscape due to the greater exposure to the sun and being inundated by high rainfall due to the Tropical Maritime Air mass moving up from the southern part of Nigeria (Adedeji, 2003). The southern facing slopes are subject to both extremes in the study area. A consequence of this extreme alteration of soild condition is a loss of soil (Ohlmacher, 2007; Iwu, 2012). Nine of the studied gullies in the study area are developing towards the south facing slopes while the remaining 5 are developing on North facing slopes. This is expected due to the north slopes being exposed to the more drying winds of the Harmattan. Values of aspect map around -1 indicate flat surfaces Appendix III. These flat areas are areas where floods, areas liable to flooding and where rivers are located. Slopes experience faster geomorphic evolution because of high rainfall received from Tropical Maritime Air Mass as reported in (Igwe,
2004). Cevik and Topal (2003; Pulice et al., 2009) report that the aspect of a slope can indirectly influence gully erosion processes, controlling the exposition to several climate conditions (duration of sunlight exposure, precipitation intensity and moisture retention). Although the studied gullies are located in numerous aspect locations, they remain dominated by those on south facing slopes where the climatic extremes are more severe.

\section{Conclusion}

Determining Causes of Gully Erosion and Associated Rates of Change in South-East Nigeria, using a Remote Sensing and GIS Methodology, was conceived out of the numerous gully developments, inaccessibility to some and the helplessness of the communities in finding solutions to the rampant problem in southeast Nigeria. The research objective is to develop a low-cost GIS and Remote Sensing methodology for monitoring and quantifying gully erosion and development over time, identifying the impact and incorporating analysis of environmental factors and land use change. This study has used low-cost remote sensing and GIS methodology to identify the factors responsible for gully formation and development. The field work was carried out in southeast Nigeria and the rest of the developmental research was carried out at the University of Brighton. The research work analysed the topography, the landcover satellite images for a period of 30 years as well as detailed interpretation of 14 gully sites from the study area. This long period of data collection and analysis provided enough information on what has been happening in the past and the anthropogenic activities that are responsible for gully development. The 14 gullies studied in detail, were traced and tracked from 1986-2015 for the older gullies and for 2006-2015 for the younger (30 and 10 Yrs period respectively). This was primarily to observe their relationship with landcover and topography of the study area.

It was observed from the analysis that as the vegetation of the study area continues to reduce, open lands and gullies continue to develop while new gullies are expected to form. The open land development that was tied to vegetation loss could be responsible for the gully development as can be found from the location of gully points overlaid on classified satellite images. In general, the tracking and tracing of the 14 gully sites showed that their occurrence and development positively correlated with vegetation removal for the 30 years' period. Exceptions were found in some year(s) when gullies were being tackled by communities, ministries and agencies to reduce or stop development. The topographical analysis of the study revealed that gullies develop mainly on slope with angle of $5^{\circ}$ and above, continuous removal of vegetation, soil (deeply weathered, unconsolidated sandy sediments and friable soils) and on 
high stream order of 1-4 stream order. Even though the topography of the area is a moderate one, it acts to help the gullies to develop in unconsolidated friable soils which are deeply weathered. The unconsolidated and deeply weathered soil enables gully incision and widening.

Three types of multivariate statistical analysis were utilised to assess and explore the gully factors extracted from the land cover and topographical analysis of the study area with limited success at determining generic driving factors to explain gully behaviour in the region. Cluster analysis, PCA and Multiple Regression were used both on data derived from proprietary and open source software with very similar results. These tests were applied to the data as a means to predict the gully factors similarity, characteristics and relationship to incipient gully generation, development and yearly proportional area gully change. The novel application of this methodology to this setting allows a low-cost GIS and Remote Sensing methodology that can be used for monitoring and quantifying gully erosion and development over time. The geospatial location of the study is appropriate as a low-cost methodology is required to help such areas. The research has determined the change in land-cover classification over a maximum 30-year period and quantification of gully extent, rates of change and rate of yearly gully change in metre squared per square metre of gully sites over identified life spans in a very successful manner which will allow site specific rather than generic trends to be identified (Iro, 2020). This study has detected changes in gully dimensions in association with Digital Elevation Models (DEM) and Mapped dynamics of deforestation and forest degradation in southeast Nigeria forests using radar satellite data and has successfully identified links between gully erosion rate and vegetation removal on the local and regional scale. This work has been conducted with the aims and the objectives earlier stated clear in mind with a key outcome being the success of the open source approach producing similar results to the more illustrious and proprietary counterparts. The significance of this being that this work can be replicated in low GDP countries with similar environmental problems.

It can be concluded that there is no single variable responsible across the region for gully formation and generation in the study area. All the identified gully variables combine to cause gully development and consistent with the literature they are shown to be driven by different variables in different locations. What is not disputed in this study is the importance of each of the variables examined on gully formation and subsequent growth with each tested variable identified from robust literature analysis and shown statistically to contribute to gully formation with the exception of elevation. By examining and establishing a list of driver variables required for gully formation, this thesis can be used to alert those concerned with gully erosion of the risk factors and drivers of this destructive phenomenon. Most importantly it has provided an accessible route to achieve this. Following the identified causes of gullies in the study area which has shown the ability of using remote sensing and GIS to monitor gully development, mitigation measures can now be put in place to prevent further gully development and be able to control already developed ones on a local and regional level and through civilian or governmental pathways.

\section{Recommendation}

As a result of the findings of this study, 3 key recommendations are offered to help in future to mitigate gully formation, generation and development in southeast Nigeria and potentially in any region having similar environmental problems:

1. Retention and infiltration of surface water should be provided in areas where runoff is high to avoid high runoff which erodes the soil from upland. Therefore, since slope, gradient and elevation is natural and cannot be changed, the retention and infiltration of runoff will be very important

2. Proper land-management practices must be employed to prevent forest fires and illegal wood logging and to avoid open lands development which can evidently lead to gully development. If the vegetal covers are allowed, it may lead to soil stabilisation, rainfall runoff retention and also control the already developed gullies but may not curb their progress entirely

3. Control of urban lands (road construction, building structures and mining) which can reduce the effect on soil and vegetation removal to avoid gully development. Since urban development is tied on the use and removal of physical environment and mining which helps to create open lands, it can be reduced and controlled, which will reduce the level of gully formation and development

\section{Acknowledgment}

I will like to use this opportunity to show appreciation to Dr Matthew Brolly, University of Brighton and Imo State University, Owerri Nigeria. They have in one way or the other contributed to the completion of this work.

\section{Ethics}

This research work was conducted by my Sylvanus Iro under the supervision of University of Brighton research standard. 


\section{References}

Abdulfatai, I. A., Okunlola, I. A., Akande, W. G., Momoh, L. O., \& Ibrahim, K. O. (2014). Review of gully erosion in Nigeria: causes, impacts and possible solutions. Journal of geosciences and geomatics, 2(3), 125-129.

Adedeji, O. O. (2003) Climatic zones for architectural design with climate in Nigeria.

Ahmed, A., \& Dinye, R. D. (2012). Impact of land use activities on Subin and Aboabo Rivers in Kumasi Metropolis. International Journal of Water Resources and Environmental Engineering, 4(7), 241-251.

Akanwa, G. K. O. (2017). Analysis of soil erosion and effects Umudike, southeast Nigeria. Journ. Of Agriculture. 3, 213-223.

Albert, A. A., Samson, A. A., Peter, O. O., \& Olufunmilayo, A. O. (2006). An assessment of the socio economic impacts of soil erosion in SouthEastern Nigeria, shaping the change. In XXIII FIG Congress Munich, Germany (p. 12).

Almeer, M. H. (2012). Vegetation extraction from free google earth images of deserts using a robust BPNN approach in HSV Space. International Journal of Advanced Research in Computer and Communication Engineering, 1(3), 134-140.

Ayanlade, A., \& Drake, N. (2016). Forest loss in different ecological zones of the Niger Delta, Nigeria: evidence from remote sensing. GeoJournal, 81(5), 717-735.

Bennard, J. K. (2012). Erosion problems in a Ghana rural community. J. Sustain. Dev. Africa, 13(2).

Beshah, T. (2003). Understanding farmers: explaining soil and water conservation in Konso, Wolaita and Wello, Ethiopia. 97(1-3), 81-93.

Bewket, W., \& Sterk, G. (2003). Assessment of soil erosion in cultivated fields using a survey methodology for rills in the Chemoga watershed, Ethiopia. Agriculture, ecosystems \& environment, 97(1-3), 81-93.

Boardman, J. (2006). Soil erosion science: Reflections on the limitations of current approaches. Catena, 68(2-3), 73-86.

Bochet, E., \& García-Fayos, P. (2004). Factors controlling vegetation establishment and water erosion on motorway slopes in Valencia, Spain. Restoration ecology, 12(2), 166-174.

Cevik, E., \& Topal, T. (2003). GIS-based landslide susceptibility mapping for a problematic segment of the natural gas pipeline, Hendek (Turkey). Environmental geology, 44(8), 949-962.

Chikwe, F. O. (2012). Gully Erosion Development in Akwa Ibom Southern Nigeria. Environmental Research. 3, 4-15.
Egboka, B. C. E., Nwankwor, G. I., \& Orajaka, I. P. (1990). Implications of palaeo-and neotectonics in gully erosion-prone areas of southeastern Nigeria. Natural Hazards, 3(3), 219-231.

Ekanade, M. O., Ibitoye, O., Jeje, L. K., Awotoye, O. O., \& Eludoyin, A. O. (2008). Characterisation of gully formed in built up area in southwestern Nigeria. Journal of Geography and Regional Planning. 1(9), 164-171.

Enabor, E. E., \& Sagau, V. O. (1988). Ecological Disasters in Nigeria: Soil Erosion (An Introduction) in Sagamu VO. Ecological Disasters in Nigeria: Soil Erosion (Federal Ministry of Science and Technology, Lagos).

Ezezika, O. C., \& Adetona, O. (2011). Resolving the gully erosion problem in Southeastern Nigeria: Innovation through public awareness and community-based approaches. Journal of soil science and Environmental Management, 2(10), 286-291.

Gobin, A. M., Campling, P., Deckers, J. A., Poesen, J., \& Feyen, J. (1999). Soil erosion assessment at the Udi-Nsukka Cuesta (southeastern Nigeria). Land degradation \& development, 10(2), 141-160.

Hudson, J. (1981). Soil and Water Conservation in Semiarid areas. Food and Agricultural Organisation.

Igbokwe, J. I., Akinyede, J. O., Dang, B., Alaga, T., Ono, M. N., Nnodu, V. C., \& Anike, L. O. (2008). Mapping and monitoring of the impact of gully erosion in Southeastern Nigeria with satellite remote sensing and Geographic Information System. The International Archives of the Photogrammetry, Remote Sensing and Spatial Information Sciences, 37, B8.

Igbozuruike, U. M. (1989). Erosion in the Agulu-Nanka Eastern Region of Nigeria. Suggestion on control measures. Conference of the Soil Science Society of Nigeria, Nsukka.

Igwe, L U. (2004). Soil erosion in the northern parts of the Orlu Uplands, Nigeria, Niger. J. Ministry of Geology. 13, 6-1.

Ijeoma, F., \& Okey, U. N. (2005). Soil degradation assessment in southeastern Nigeria, Erosion processes as quantified by Rainfall, M. (Ed), (pp. 51-63), Nigeria Geographic.

Iloeje, P. N. (2010). A New Geography of Nigeria. Longman Nigeria. Published by Longman, United Kingdom.

Iro, S. (2020). Land-Cover Removal and Gully Development in Southeast Nigeria: A 30-Year Analysis with Pixel and OBIA Approaches in Juxtaposition.

Iwu, P. C. (2012). Managing risks and increasing resilience in climate change: A case study Niger river flooding adaptation. Environment Agency. 1, 203-212 
Kosmas, C., Danalatos, N., Cammeraat, L. H., Chabart, M., Diamantopoulos, J., Farand, R., ... \& Mizara, A. (1997). The effect of land use on runoff and soil erosion rates under Mediterranean conditions. Catena, 29(1), 45-59.

Lash, K., Maduka, O. P. \& Nwachukwu, L. G. (1996). The role of soil in the Gully erosion development in Anambra, Nigeria. Hydrology. 7(3), 358-389.

Lee, N. W. \& Liu, C. H. (2006). Determinants of the adjustment of expatriate managers to foreign countries: An empirical study. International Journal of Management, 23(2), 302.

Marquisee, J. A. (2010). Factors Influencing Gully Development on Roadcuts in Southeastern Ohio (Doctoral dissertation, Ohio University).

Martinez-Casasnovas, J. A. (2003). A spatial information technology approach for the mapping and quantification of gully erosion. Catena, 50(2-4), 293-308.

Nachtergaele, F. O. F., Van Lynden, G. W. J., \& Batjes, N. H. (2002). Soil and terrain databases and their applications with special reference to physical soil degradation and soil vulnerability to pollution in central and eastern Europe. Advances in Geoecology (Netherlands).

NASA. (1999). Human Exploration and Operations. National Air Space Agency. https:/www.nasa.gov/directorates/heo/reports/1999/ index.html

Nekatet, E. R. (2006). Monitoring characterization and controlling of flood water erosions using remote sensing techniques. Journal of Geology. 54 (4), 298-323.

Njoku, F. G., Ekeigwe, H. N., \& Ogoke, M. (2014). Water erosion Prediction in Delta State Nigeria. NEST, 5, 59-77.

Nwaigwe, P. N., Aguh, U., \& Okronkwo, H. (2009). An assessment of socio-ecomic impact (effects) of Anambra Gully erosion, Anambra State Southern Nigeria. Environmental Science Journal. 2, 35-50.

Nwilo, P. C., Olayinka, D. N., Uwadiegwu, I., \& Adzandeh, A. E. (2011). An assessment and mapping of gully erosion hazards in Abia State: A GIS approach. Journal of Sustainable Development, 4(5), 196.

Odemerho, F. O., \& Sada, P. (2002). The role of urban surface characteristics on the extent of Gullies in Auchi. Applied Geography. 4, 333-344

Ofomata, G. E. K. (2002). Geology in Ofomata (ed) A survey of the Igbo Nation Africa. Onitsha: FEP.

Ofomata, G. E. K. (2008). Soil erosion in the Enugu area of Nigeria. Niger Geography. J. 8(1), 45-59.

Ohlmacher, G. C. (2007). Plan curvature and landslide probability in regions dominated by earth flows and earth slides. Engineering Geology, 91(2-4), 117-134.
Okagbue, C. O., \& Uma, K. O. (1987). Environmental and soil factors in relation to Agriculture in Nigeria. In: General Agriculture: Principles and practices, (pp 109120.) University of Nigeria Press Ltd. Nigeria.

Onwumerobi, A. (2002). Predicting Soil Erosion by Water: A Guide to Conservation Planning. FUTO Department of Agriculture. 3, 53-74

Onyekwere, J. K. (2001). The Effect of Human Impact on Ground Cover and Subsequent Erosion in Southeast Nigeria. Environmental Research, 3, 55-63.

Pimentel, D. (2004). Livestock production and energy use.

Poesen, J., Nachtergaele, J., Verstraeten, G., \& Valentin, C. (2003). Gully erosion and environmental change: importance and research needs. Catena, 50(2-4), 91-133.

Prosser, I. P., \& Slade, C. J. (1994). Gully formation and the role of valley-floor vegetation, southeastern Australia. Geology, 22(12), 1127-1130.

Pulice, I., Scarciglia, F., Leonardi, L., Robustelli, G., Conforti, M., Cuscino, M., ... \& Critelli, S. (2009). Studio multidisciplinare di forme e processi denudazionali nell'area di Vrica (Calabria orientale). Memorie della Società Geografica Italiana, 87(I-II), 403-417.

Qing-Quan, L. I. U., Li, C., \& Jia-Chun, L. (2001). Influences of slope grandient on soil erosion. Applied Mathematics and Mechanics, 22(5), 510-519.

UNDP, U. (2015). Human development report 2015: Work for human development. United Nations Development Programme.

Vajcnerova, I., Sacha, J., \& Ryglova, K. (2011). Using PCA for ananlysis of a tourist distination. ACTA University of Agriculture. LX, 449-458.

Valentin, C., Poesen, J., \& Li, Y. (2005). Gully erosion: impacts, factors and control. Catena, 63(2-3), 132-153.

Van der Veen, M. (2010). Agricultural innovation: invention and adoption or change and adaptation? World Archaeology, 42(1), 1-12.

Virginia Geospatial. (2011). Virginia View - Digital Atlas of Virginia. https://virginiaview.cnre.vt.edu/

Wisner, B., Blaikie, P., Cannon, T., \& Davis, I. (2004). At Ris-natural hazards, people's vulnerability and disasters. Wiltshire: Rout ledge.

Yu, C. C., Quinn, J. T., Dufournaud, C. M., Harrington, J. J., Rogers, P. P., \& Lohani, B. N. (1998). Effective dimensionality of environmental indicators: a principal component analysis with bootstrap confidence intervals. Journal of Environmental Management, 53(1), 101-119.

Zevenbergen, L. W., \& Thorne, C. R. (1987). Quantitative analysis of land surface topography. Earth surface processes and landforms, 12(1), 47-56. 